\title{
FIBER-OPTIC DISTRIBUTED TEMPERATURE SENSING: A NEW TOOL FOR ASSESSMENT AND MONITORING OF HYDROLOGIC PROCESSES
}

\author{
John W. Lane, Jr., U.S. Geological Survey, Storrs, CT \\ Frederick D. Day-Lewis, U.S. Geological Survey, Storrs, CT \\ Carole D. Johnson, U.S. Geological Survey, Storrs, CT \\ Cian B. Dawson, U.S. Geological Survey, Storrs, CT \\ David L. Nelms, U.S. Geological Survey, Richmond, VA \\ Cheryl A. Eddy-Miller, U.S. Geological Survey, Cheyenne, WY \\ Jerrod D. Wheeler, U.S. Geological Survey, Riverton, WY \\ Charles F. Harvey, Massachusetts Institute of Technology, Cambridge, MA \\ Hanan Karam, Massachusetts Institute of Technology, Cambridge, MA
}

\begin{abstract}
Fiber-optic distributed temperature sensing (FO DTS) is an emerging technology for characterizing and monitoring a wide range of important earth processes. FO DTS utilizes laser light to measure temperature along the entire length of standard telecommunications optical fibers. The technology can measure temperature every meter over FO cables up to 30 kilometers (km) long. Commercially available systems can measure fiber temperature as often as 4 times per minute, with thermal precision ranging from 0.1 to $0.01^{\circ} \mathrm{C}$ depending on measurement integration time.

In 2006, the U.S. Geological Survey initiated a project to demonstrate and evaluate DTS as a technology to support hydrologic studies. This paper demonstrates the potential of the technology to assess and monitor hydrologic processes through case-study examples of FO DTS monitoring of streamaquifer interaction on the Shenandoah River near Locke's Mill, Virginia, and on Fish Creek, near Jackson Hole, Wyoming, and estuary-aquifer interaction on Waquoit Bay, Falmouth, Massachusetts. The ability to continuously observe temperature over large spatial scales with high spatial and temporal resolution provides a new opportunity to observe and monitor a wide range of hydrologic processes with application to other disciplines including hazards, climate-change, and ecosystem monitoring.
\end{abstract}

\section{Introduction}

Temperature measurements can reveal diverse geologic and hydrogeologic processes such as volcanism; heat flux in geothermal reservoirs; aquifer and basin-scale ground-water flow (Beck and others 1989; Taniguchi, 1994); submarine ground-water discharge in coastal environments (Taniguchi and others, 2006); and ground-water/surface-water interaction in riverine, lacustrine, and wetland environments (e.g., Lapham, 1989; Smith and Hinchee, 1993; Constantz and Stonestrom, 2003). Recent advances in temperature sensor technology have renewed interest in the use of temperature to monitor earth processes with important implications for water-resources management, environmental engineering, and habitat conservation. For a recent review on heat as a hydrologic tracer, see Anderson (2005).

Fiber-optic distributed temperature sensing (FO DTS) technology developed and commercialized in the last decade supplements conventional discrete-point and remote-sensing technologies for temperature measurement. FO DTS systems use laser light traversing optical telecommunication fibers to continuously measure temperature along the entire fiber length. Although instrumentation capabilities are improving rapidly, single- and multi-channel systems are currently capable of measuring the 
temperature of fibers as long as 30 kilometers $(\mathrm{km})$ with thermal resolution ranging from 0.1 to $0.01{ }^{\circ} \mathrm{C}$, spatial resolution of 1 meter (m), and temporal resolution on the order of seconds to minutes, subject to a trade-off between fiber length and spatial resolution effects resulting from measurement averaging or "stack" time.

In May 2006, the U.S. Geological Survey (USGS), Office of Ground Water, Branch of Geophysics acquired a commercial FO DTS system and initiated a project to demonstrate and evaluate hydrologic applications of the technology. The demonstration project included deployments for a total of six studies; here, we briefly review FO DTS technology and present examples of FO DTS data from three field deployments in Virginia, Wyoming, and Massachusetts.

\section{Method}

FO DTS involves propagation of a laser pulse along an optical fiber and the measurement and analysis of light backscattered by the fiber. Because the propagation velocity of light in a fiber is known (or can be measured), the location of a measurement "point" can be determined by careful timing of the scattered light arrivals relative to the incident pulse; the temperature at the point is determined through analysis of the backscattered light in terms of temperature-sensitive mechanisms (including Brillouin and Raman scatter). Both optical time-domain reflectometry (OTDR) and optical frequency-domain reflectometry (OFDR) methods are used for data analysis in commercially available systems. The spatial and thermal resolution of the measurements can be improved through averaging (or "stacking") of multiple measurements. For additional details, the interested reader is directed to Selker and others (2006).

The USGS FO DTS evaluation project used a 2-channel Lios OTS- $2^{1}$ system with a range of $2 \mathrm{~km}$ per channel. The Lios system utilizes "Raman scatter" and OFDR analysis to estimate temperature along the fiber. Raman scatter is a phenomenon whereby light traversing an optical fiber is scattered by random imperfections and inhomogeneities in the structure of the glass. This scattering results in the emission of light at frequencies below (Stokes) and above (anti-Stokes) the frequency of the incident light. The amplitude of the light scattered at the anti-Stokes frequency is sensitive to the temperature of the fiber at the point of scatter; variations in the amplitude of the anti-Stokes scatter are used to determine temperature along the length of the measurement fiber (Colthup and others, 1990).

\section{Field Studies}

In this paper, we summarize FO DTS field deployments conducted to evaluate ground-water/surfacewater interaction at three sites across the United States: (1) Shenandoah River, Virginia, (2) Fish Creek, Wyoming, and (3) Waquoit Bay, Massachusetts (Figure 1).

\section{Shenandoah River, Clarke County, Virginia}

The goal of the Shenandoah River project was to evaluate the ability of FO DTS to delineate zones of cool ground-water discharge from fractured-rock and karst aquifers into the relatively warm river. For this field deployment, two 1.3-km FO cables were placed down the middle and one $300-\mathrm{m}$ cable was placed about 25-m from the north bank of the Shenandoah River in the Lockes Mill area of Clarke County, Virginia, in August 2006. The FO cable was deployed parallel to the river current to minimize cable strain, which can manifest as spurious changes in temperature. Large washers were used to weight the FO cables in order to keep the fibers on the river bottom. Figure 2 shows an example of the

\footnotetext{
${ }^{1}$ Any use of trade, product, or firm names is for descriptive purposes only and does not imply endorsement by the U.S. Government.
} 


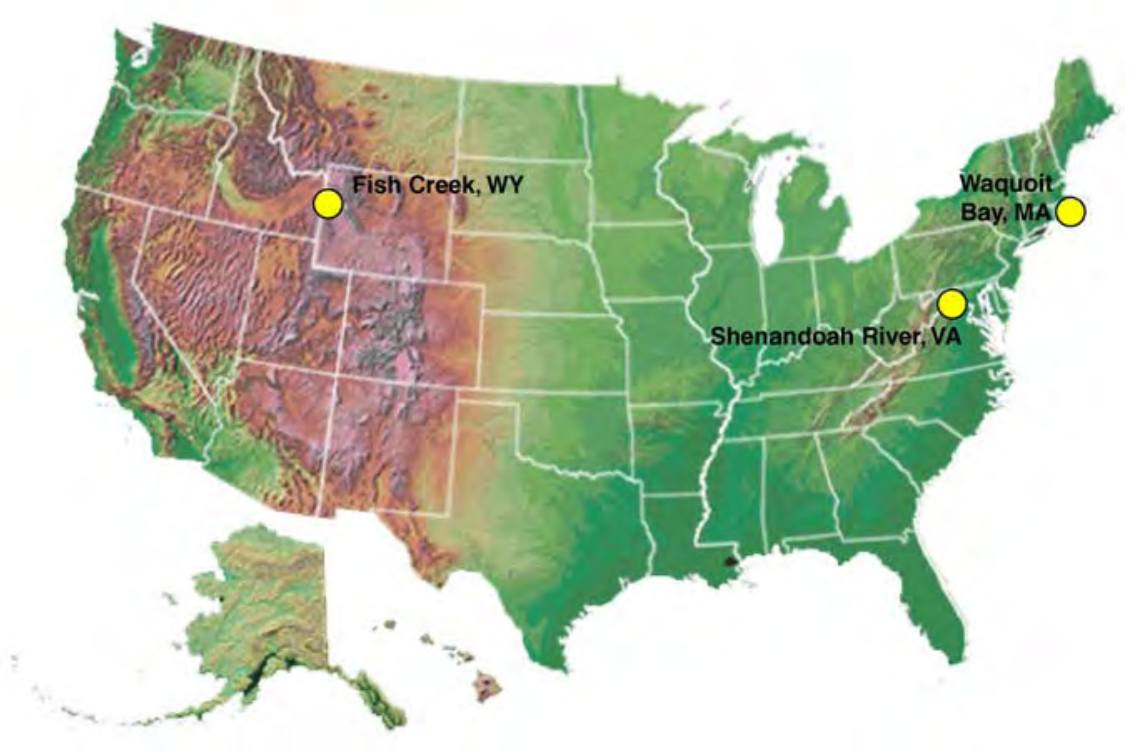

Figure 1: Field sites in Wyoming, Virginia, and Massachusetts.

FO DTS instrument field display and a highlighted low-temperature thermal anomaly that correlates with spring-water discharge to the river. A two-dimensional display of temperature along the 300-m cable is shown plotted against time in Figure 3. The low-temperature anomaly at the 200-m mark along the cable is interpreted as a zone of focused ground-water discharge to the river.

Using conventional methods, a field crew could likely have measured temperature at up to 100 locations over one or two days. In contrast, using FO DTS, about one million temperature readings were taken in about three days, with greater spatial and temporal resolution than possible using discrete-point measurement instruments.

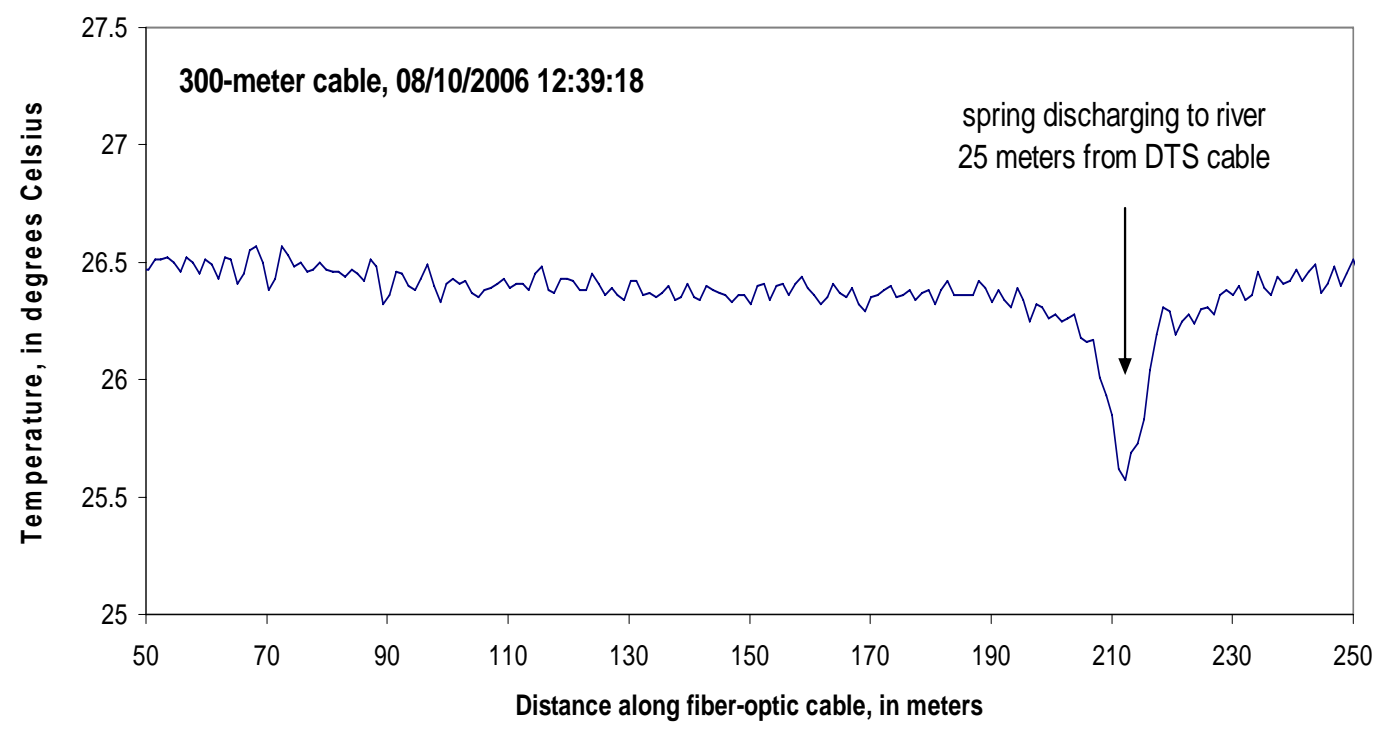

Figure 2: Temperature data showing thermal anomaly, Shenandoah River, Clarke County, Virginia. 


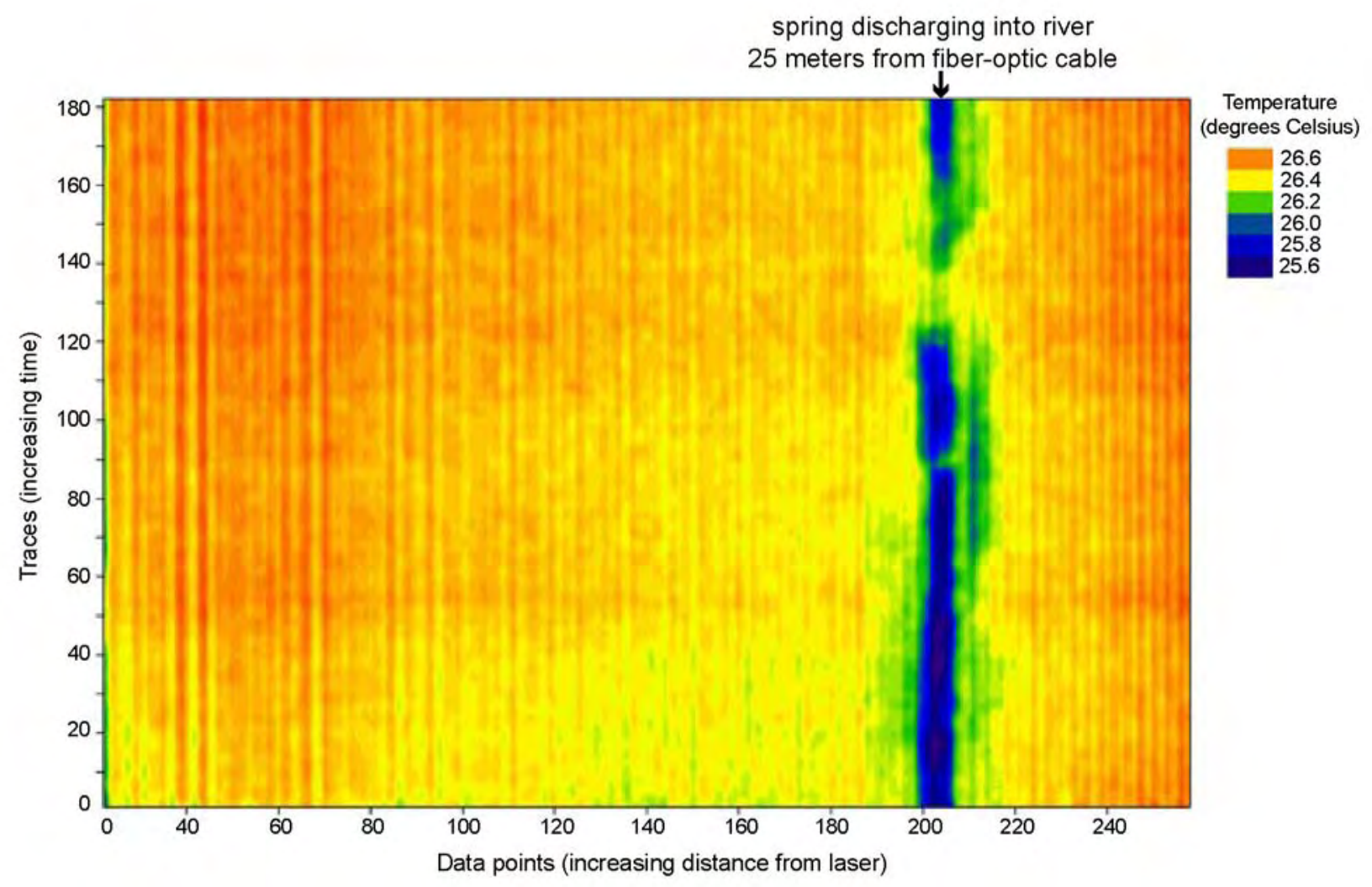

Figure 3: Two-dimensional display of temperature data showing thermal anomaly, Shenandoah River, Clarke County, Virginia. Data collected with 300-meter fiber, 08/10/2006, 12:10:28 to 15:10:36.

\section{Fish Creek, Jackson Hole, Wyoming}

For the Fish Creek project, FO DTS cable was deployed along a 1-km reach of Fish Creek in Jackson Hole, Wyoming. Similar to the Shenandoah River project, the goal of the Fish Creek project was to evaluate the ability of FO DTS to delineate zones of focused ground-water discharge into the creek. The FO DTS cable was anchored to the streambed, and temperature measurements were made over a continuous 27-hour period in July 2006 to obtain a set of daytime and nighttime data. Figure 4 shows the track line of the FO cable, overlain on an aerial photo of the site. Temperature anomalies have been enhanced by subtracting the average cable temperature from each point in the data set. The FO DTS data were used to identify reaches with lower temperature and less temperature fluctuation, suggestive of focused ground-water discharge, for follow-up direct temperature measurements. In this example, FO DTS provided valuable, cost-effective reconnaissance information useful for characterizing ground-water and surface-water interactions in a stream environment (Wheeler and others, 2007). 


\section{Residual Cable Temperature \\ 7/15/2006 3:44:57 PM}

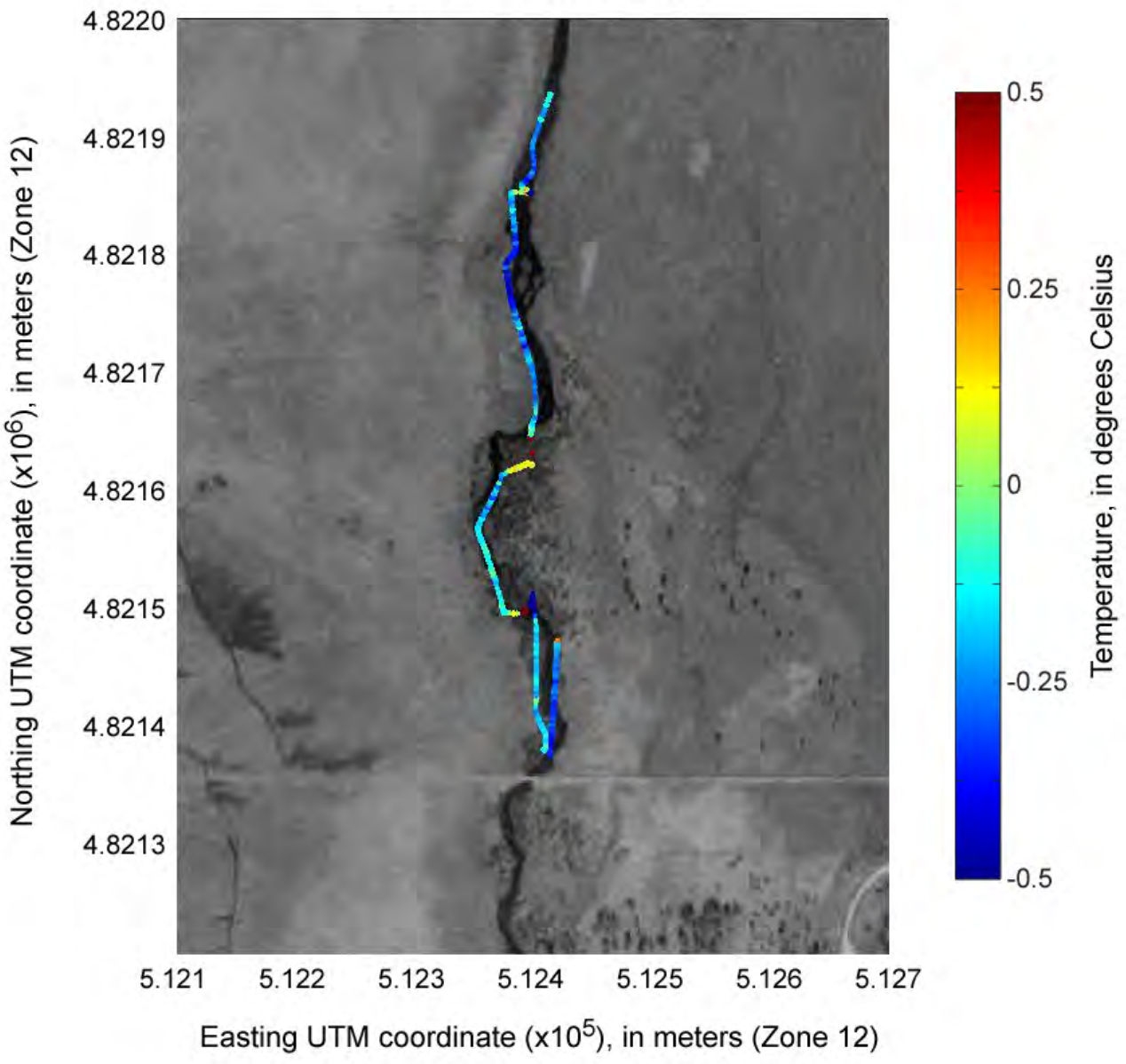

Figure 4: Track line of temperature data overlain on aerial photo of site for a set of de-meaned temperature measurements, Fish Creek, Wyoming.

\section{Waquoit Bay, Falmouth, Massachusetts}

The goal of the Waquoit Bay FO DTS project was to evaluate the ability of FO DTS to identify and characterize aquifer-estuary interaction at the Waquoit Bay National Estuarine Research Reserve (WBNERR), East Falmouth, Massachusetts (Figure 5). Several studies have been conducted at the WBNERR to examine aquifer-estuary interaction, including Michael and others (2003, 2005), Abraham and others (2003), and Valiela and others (1990). Using seepage-meter data and other measurements acquired over several field seasons, Michael and others (2005) developed an understanding of the spatial and temporal patterns and variability in submarine ground-water discharge (SGD) in the Bay. They divided the near-shore region into three zones: a near-shore zone (0 to $5 \mathrm{~m}$ from shore) of tidedependent fresh SGD; an intermediate zone (5 to $30 \mathrm{~m}$ ) of tide-dependent saltwater-sediment estuary exchange; and a zone beyond about $30 \mathrm{~m}$ of seasonally driven sediment-estuary saltwater exchange.

For the FO DTS deployment, the FO cable was deployed in a zigzag pattern over a 60 by $80-\mathrm{m}$ grid (Figure 5), buried beneath the estuary-floor sediments to a depth of about 10 centimeters (cm). A strong, nylon supporting rope was attached to the FO cable every few meters to provide strain relief, particularly at the turns of the zigzag grid. During the 2-week study period in May and June 2006, water 
temperature in Waquoit Bay was $5-10^{\circ} \mathrm{C}$ warmer than the ground water; hence, cold temperature anomalies identified on the FO DTS grid are indicative of SGD. Figure 6 shows a time series of FO DTS-measured estuary-floor temperature, with clear indication of near-shore SGD around low tides. Spatially averaged temperature data for different intervals from the shore also show the decreasing tidal influence on estuary-bottom temperature with increasing distance from shore (Figure 7). Consistent with the findings of Michael and others (2005), correlations between FO DTS bottom temperature timeseries and measured water-column temperatures delineate a tide-dependent zone of SGD, extending from shore to about $5 \mathrm{~m}$, and an intermediate zone of tide-dependent sediment-estuary saltwater exchange from 5 to about $30 \mathrm{~m}$ offshore. These findings are consistent with measurements of seepage and sediment salinity at the site, as well as previous numerical modeling and field experimental evidence (Michael and others, 2005). The Waquoit Bay results demonstrate the potential for FO DTS technology to characterize SGD, which represents an important and poorly understood pathway for nutrients, chemicals, and contaminants to reach coastal waters.

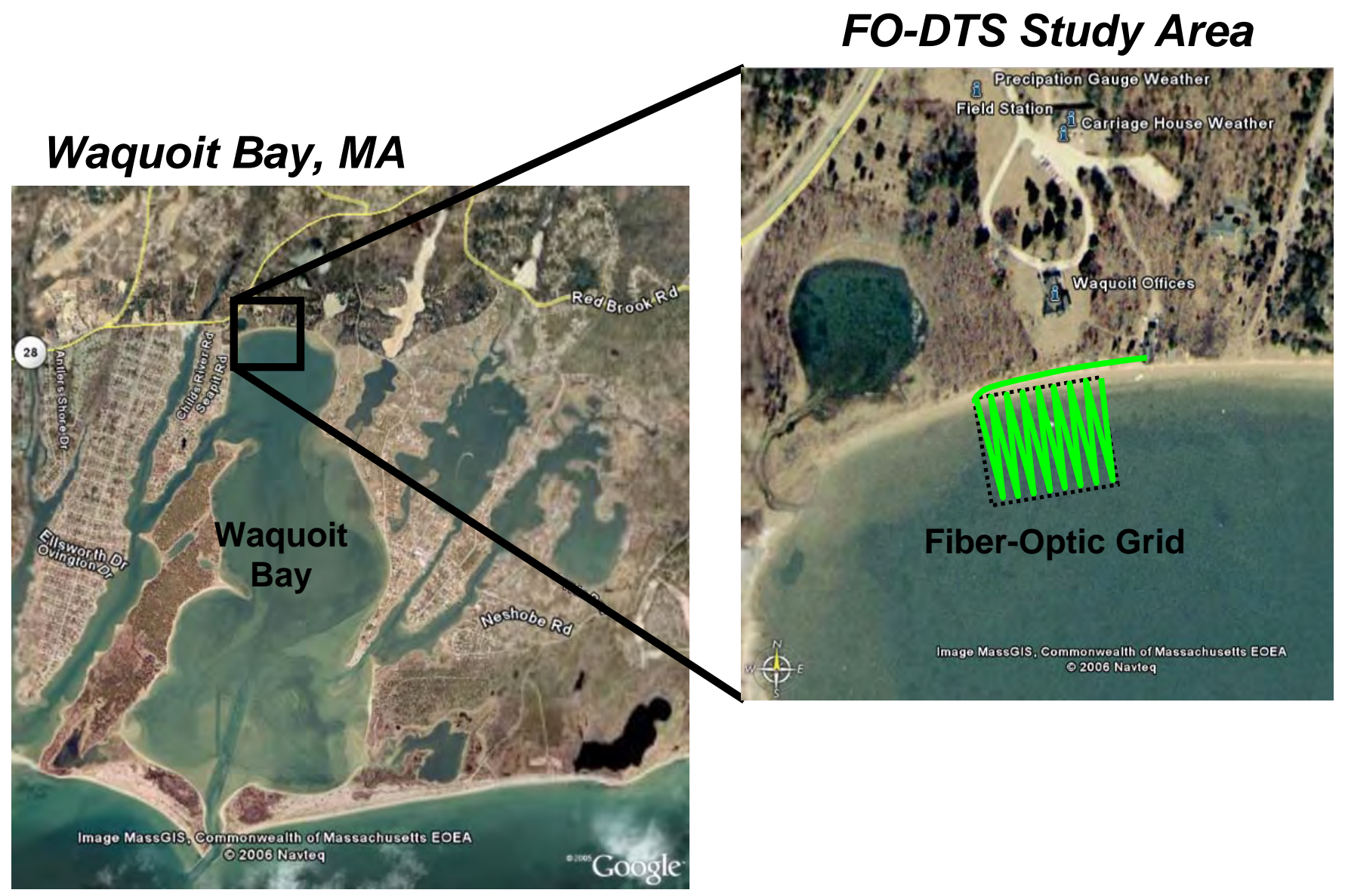

Figure 5: Waquoit Bay, Cape Cod, Massachusetts, and track of fiber-optic cable (green). 
(a) Low tide, 6/14/2006 9:45:07 PM

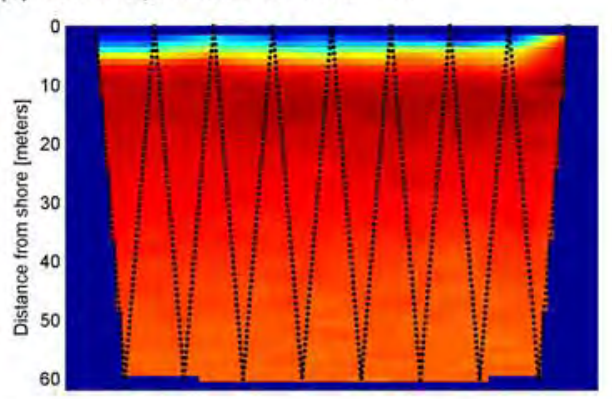

(b) Rising tide, 6/15/2006 12:06:44 AM

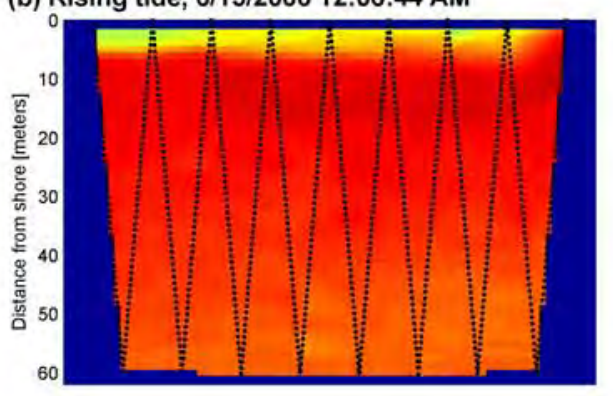

(c) Near high tide, 6/15/2006 2:28:20 AM

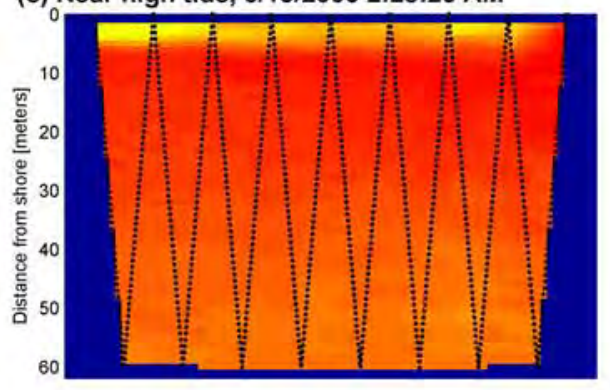

(d) Falling tide, 6/15/2006 4:49:56 AM

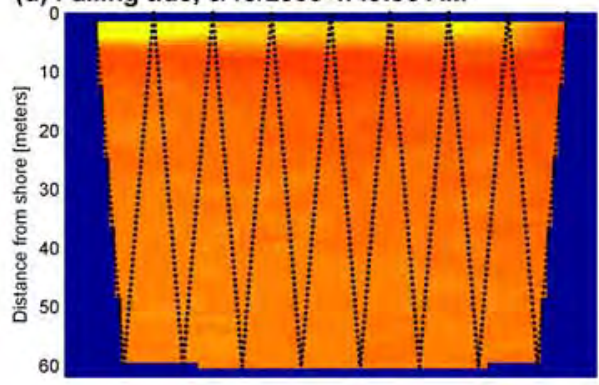

(e) Near low tide, 6/15/2006 9:33:12 AM

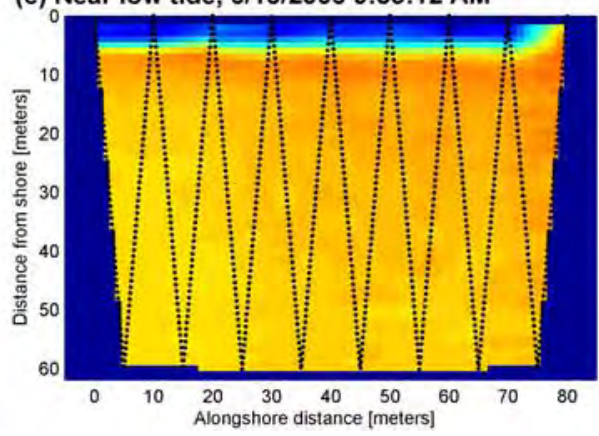

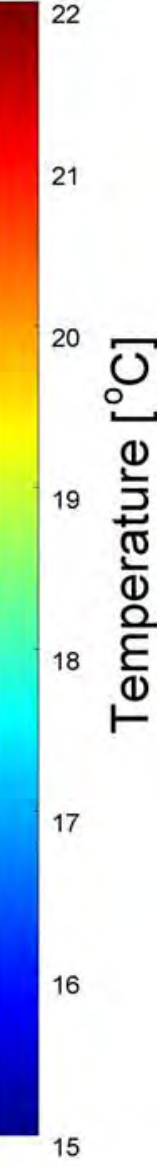

Figure 6: Time-lapse series of fiber-optic distributed temperature sensing bay-floor temperature data for (a) near low tide, (b) rising tide, (c) near high tide, (d) falling tide, and (e) near low tide, Waquoit Bay, Cape Cod, Massachusetts. Black dots indicate locations along cable where measurements are made. Temperature is interpolated linearly over a 1-meter pixelated grid. 


\section{(a) DTS Spatial Average}

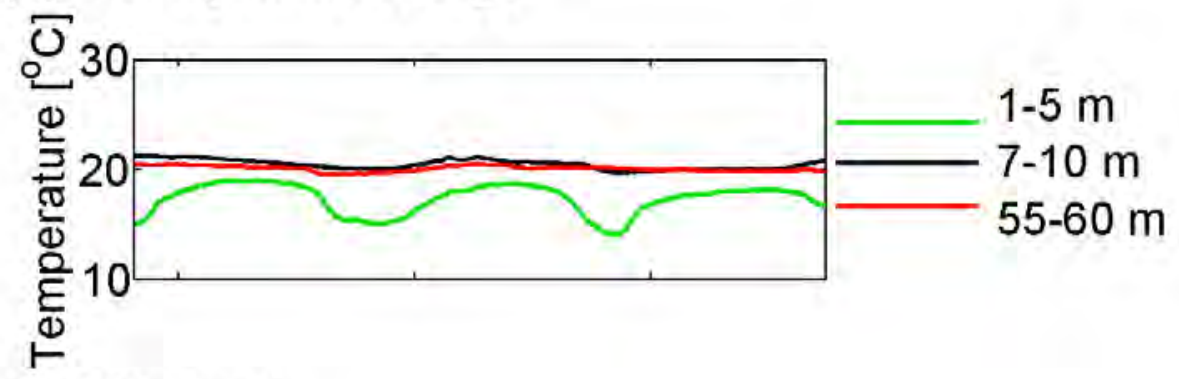

\section{(b) Tide level}

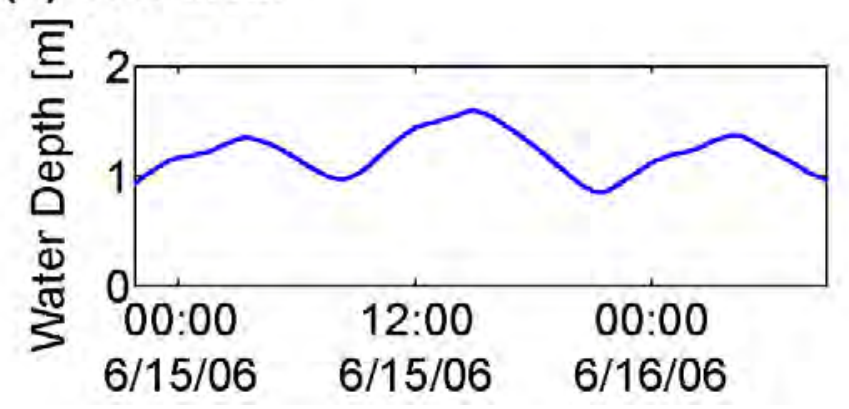

Figure 7: (a) Fiber-optic distributed temperature sensor (DTS) data averaged spatially for three different intervals from shore: 1-5, 7-10, and 55-60 meters (m), and (b) tide level. The data show colder temperatures at low tide near shore, with tidal influence decreasing with distance offshore.

\section{Conclusions}

FO DTS is an emerging technology with the potential to provide insight into hydrologic processes over a wide range of spatial and temporal scales. Three case studies, conducted in Virginia, Wyoming, and Massachusetts, demonstrated the application of FO DTS to help understand streamaquifer and estuary-aquifer interaction. Experimental results from the Shenandoah River, Clarke County, Virginia, indicated a cold anomaly associated with a spring that discharged to the stream. FO DTS data from a 1-km section of Fish Creek, Jackson Hole, Wyoming, were used in developing a plan for targeted sampling of cold anomalies, which are suggestive of focused ground-water discharge. Results from Waquoit Bay, Massachusetts, show that FO DTS technology can provide insight into submarine groundwater discharge. We stress that, in these studies, FO DTS does not replace conventional measurements, but rather provides (1) additional context for interpretation of point measurements, and (or) (2) costeffective reconnaissance information over large areas as a basis for more targeted, detailed sampling.

This USGS demonstration and evaluation project continues, with ongoing or planned projects focused on using FO DTS (1) in boreholes, to understand fractured-aquifer hydraulics; (2) in streams, to understand hyporheic exchange; and (3) in estuaries, combined with other geophysical information to further our understanding of the timing and spatial distribution of submarine ground-water discharge. 


\section{References}

Abraham, D.R., Charette, M.A., Allen, M.C., Rago, A., and Kroeger, K.D., 2003, Radiochemical estimates of submarine groundwater discharge to Waquoit Bay, Massachusetts, Biological Bulletin, v. 205, p. 246-247.

Anderson, M.P., 2005, Heat as a groundwater tracer, Ground Water, v. 43, no.6, p. 951-968.

Beck, A.E., Garven, G., and Stegena, L., 1989, Hydrogeological regimes and their subsurface thermal effects, Geophysical Monograph 47, American Geophysical Union, Washington, D.C.

Colthup, N.B., Daly, L.H., and Wiberley, S.E., 1990, Introduction to Infrared and Raman Spectroscopy (3rd Edition) Academic Press.

Constantz, J., and Stonestrom, D.A., 2003, Heat as a tool for studying the movement of groundwater near streams, U.S. Geological Survey Circular 1260, 96 p.

Hinchee, R.E., and Smith, L.A., 1993, In situ thermal technologies for site remediation: Boca Raton, Florida, CRC Press, 224 p.

Lapham, W.W., 1989, Use of temperature profiles beneath streams to determine rates of vertical groundwater flow and vertical hydraulic conductivity, U.S. Geological Survey Water-Supply Paper 2337.

Michael, H.A., Lubetsky, J.S., and Harvey, C.F., 2003, Characterizing submarine groundwater discharge: A seepage meter study in Waquoit Bay, Massachusetts, Geophysical Research Letters, v. 30, doi:10.1029/GL016000.

Michael, H.A., Mulligan, A.E., and Harvey, C.F., 2005, Seasonal oscillations in water exchange between aquifers and the coastal ocean, Nature, v. 436, p. 1145-1148.

Selker, J.S., Thévenaz, L., Huwald, H., Mallet, A., Luxemburg, W., van de Giesen, N., Stejskal, M., Zeman, J., Westhoff, M., and Parlage, M., 2006, Distributed fiber optic temperature sensing for hydrologic systems, Water Resources Research, v. 42, W12202, doi:10.1029/2006WR005326.

Taniguchi, M., 1994, Estimated recharge rates from groundwater temperatures in the Nara Basin, Japan, Hydrogeology Journal 2, no. 4: 7-14.

Taniguchi, M., Tomotoshi, I., and Shimada, J., 2006, Dynamics of groundwater discharge and freshwater-seawater interface, Journal of Geophysical Research, v. 111, C01008, doi:10.1029/2005JC002924.

Wheeler, J.D., Eddy-Miller, C.A., Constantz, J.E., and Leemon, D.J., 2007, Determination of groundwater and surface-water interactions using multiple methods, in and near Fish Creek, Jackson Hole, Wyoming, U.S. Geological Survey National Surface-Water Conference and Hydroacoustics Workshop, Saint Louis, Missouri, April 2-6, 2007.

Valiela, I., Costa, J., Foreman, K., Teal, J.M., Howes, B., and Aubrey, D., 1990, Transport of groundwater-borne nutrients from watersheds and their effects on coastal water, Biogeochemistry, v. 10, no. 3, p. 177-197.

\section{Acknowledgments}

Projects described in this paper were supported by the USGS Ground-Water Resources Program, the USGS Virginia and Wyoming Science Centers, and the Teton Conservation District.

Final copy as submitted to SAGEEP for publication as: Lane, J.W., Jr., Day-Lewis, F.D., Johnson, C.D., Dawson, C.B., Nelms, D.L., EddyMiller, C.A., Wheeler, J.D., Harvey, C.F., and Karam, H., 2008, Fiber-optic distributed temperature sensing: A new tool for assessment and monitoring of hydrologic processes, in Symposium on the Application of Geophysics to Engineering and Environmental Problems, April 610, 2008, Philadelphia, Pennsylvania, Proceedings: Denver, Colorado, Environmental and Engineering Geophysical Society, 9 p. 